Oliver Budzinski

Media-revenue allocation in Formula One : a case for competition policy?

URN: urn:nbn:de:gbv:ilm1-2015200239

Autorenversion des Beitrags zum Blog:

Medien - Märkte - Meinungen : M-Blog. - Hamburg : Ralf Dewenter.

Beitrag vom 5. Oktober 2015

URL: $\quad$ http://www.m-blog.info/2015/10/media-revenue-allocation-informula-one-a-case-for-competition-policy/

[Gesehen: 09.12.2015] 


\title{
Media-Revenue Allocation in Formula One - A Case for Competition Policy?
}

\author{
Oliver Budzinski*
}

Published online in M-Blog (http://www.m-blog.info/2015/10/media-revenue-allocation-informula-one-a-case-for-competition-policy/) on the 5th of October 2015.

\begin{abstract}
Two midfield teams competing in the FIA Formula One World Championship (motor racing), have reportedly lodged a formal complaint to the European Commission. They raise two concerns about violations of competition law. First, the system of allocating media revenues (predominantly from the sale of broadcasting rights) between the participating teams is allegedly unlawful and unfair because of non-performance related extra payments to some teams and a heavily front-biased performance-related distribution scheme. Second, the system of rule-making in F1 is unlawful and unfair because some teams have more influence on rules and rule-changes than others. According to the complainants, the commercial rights holder $(\mathrm{CRH})$ abuses its power to benefit certain teams over others and forms a cartel with the favored teams as well as the governing sports authority in order to set the rules in an anticompetitive way for the complaining teams. This comment argues that an investigation into Formula One's revenue and governance structure is justified since there is ample indication of anticompetitive arrangements.
\end{abstract}

Keywords: Formula One motor racing, antitrust, competition policy, sports, economics, abuse of power, media economics, broadcasting rights

JEL-Codes: K21, L12, L40, L83, Z20

\footnotetext{
* Prof. Dr. Oliver Budzinski, Professor of Economic Theory, Institute of Economics, Institute of Media and Mobile Communication, Ilmenau University of Technology, Germany, email: oliver.budzinski@tu-ilmenau.de.
} 


\section{Introduction}

Force India and Sauber, two midfield teams competing in the FIA Formula One World Championship (motor racing), have reportedly lodged a formal complaint to the European Commission. ${ }^{1}$ They raise two concerns about violations of competition law:

(A) The system of allocating media revenues (predominantly from the sale of broadcasting rights) between the participating teams is allegedly unlawful and unfair because of non-performance related extra payments to some teams and a heavily front-biased performance-related distribution scheme.

(B) The system of rule-making in F1 is unlawful and unfair because some teams have more influence on rules and rule-changes than others.

The FIA Formula One World Championship (F1) by some accounts represents the second biggest sports business in the world. Its media revenues amount to approx. 1.5 bn $€$ per year, of which about 60 per cent is distributed among the teams participating in F1. According to the complainants, the commercial rights holder $(\mathrm{CRH})$ abuses its power to benefit certain teams over others and forms a cartel with the favored teams as well as the governing sports authority in order to set the rules in an anticompetitive way for the complaining teams. F1 has already been subject to a competition policy intervention about 15 years ago, which has crucially influenced the governance structure that is now complained about. Thus, the current problems also reveal a major flaw in the 2001 agreement (European Commission 2001): instead of restoring competition, market power may just have been leveraged to the commercial rights holder.

\section{Background}

\footnotetext{
${ }^{1}$ See http://www.bbc.co.uk/sport/0/formula1/34388544 (2015-10-05).
} 
In 1999, the European Commission (EC) formally opened proceedings against the Fédération Internationale l'Automobile (FIA) because it was abusing its dominant position as the principal world authority on motor racing championships in order to deter any rival competitions from its own premium championships (in particular F1). As one of the main problems, the EC identified the intermixture of FIA's role as a regulatory authority with its own business interests as the commercial rights holder of its premium racing series. While the dominant position of a market-internal regulatory authority is accepted by the EC as a special characteristic of professional sports - the necessity of centrally setting and enforcing common rules for any sports competition, league or championship - the EC's concern was with the effects of this powerful position on the commercial side of the business, in particular the exploitation of media rights. Consequently, the EC was adamant to achieve a separation of powers and settled the case in 2001 after the FIA agreed to sell all F1 commercial rights. This separation of regulatory and commercial functions was implemented by FIA reportedly selling the exclusive license to exploiting the commercial rights of $\mathrm{F} 1$ to a private company called Delta Topco for a 100 period (2010-2110) in exchange of one-off fixed fee of US\$ 313.6 million. ${ }^{2}$ Nowadays, the major shareholder of F1's commercial rights holder (CRH) is the private equity company CVC (through a complex chain of companies and subsidiaries). After a monitoring period, the EC concluded in 2003 that the separation had been successful and competition restored in worldwide commercial motor racing.

\section{A 100 Year Monopoly}

However, since 2001, the concern of an abuse of commercial power has sort of shifted away from the FIA to the CRH. Against the background of annual profits from media revenues in

\footnotetext{
2 See http://www.forbes.com/sites/csylt/2014/11/26/european-commission-investigating-f1-anticompetition-allegations/ (2014-12-23).
} 
excess of 1 bn $€$, the 100 year exclusive license for the one-off fee of less than $€ 300$ million appears to be a real bargain. Furthermore, it hands the 100-year-exclusive CRH a powerful position vis-à-vis the participants of F1 (teams, circuit owners, suppliers, etc.). In contrast to other sports, F1's CRH belongs to a profit-oriented, private equity-owned business company and not to a sporting authority, which at least formally is committed to the common welfare of the sport. The allocation of media revenues was established through bilaterally-negotiated agreements between each team and the $\mathrm{CRH}$ and does not represent a collective decision of participating teams like in other professional sports.

\section{Anticompetitive Distribution of Media Revenues?}

It is quite common in professional sports to use collectively earned media revenues as a means to promote competitive balance and a level playing field of win opportunities. The more successful teams already enjoy significant budget advantages in terms of sponsorship revenues, merchandising income, etc. Therefore, revenues from broadcasting rights are often allocated rather equally among the participating teams in order to contribute to keeping the championship or league competition close and, thus, attractive for fans (consumers). A completely equal distribution of media money, however, does not provide additional incentives to win, in particular, in the midfield region of a league or a championship. Thus, most professional sports combine an equal basic distribution with some performance-related elements. For instance, in the Premier League, one of the most profitable professional leagues in the world, 50 percent of the revenues are distributed equally, 25 per cent according to sporting success (ranking positions) and 25 per cent according to the number of live broadcasts of the team per season. As a result, the lowest paid team (from the bottom of the ranking) still receives roughly 60 per cent of the payment that the best paid team (the winner) gets. 
In F1, the payment scheme is drastically skewed towards selected big teams. ${ }^{3}$ The allocation scheme rests on two pillars: first, a performance-related distribution (according to constructor championship rankings) and, second, non-performance-related (so-called) heritage payments to selected teams. The latter were individually negotiated with the $\mathrm{CRH}$, with five teams annually receiving between more than 90 million US\$ (Ferrari) and about 10 million US\$ (Williams). The other (currently five) teams receive no such extra payments. These heritage-bonuses, which were individually negotiated between the $\mathrm{CRH}$ and the respective teams at a time when these teams threatened to form a rival series to F1, ostensibly reflect the historical value of these teams to F1. There is no basic equal distribution like in the Premier League. Both pillars - performance-related money and heritage payments combined yield an allocation where the lowest paid team receives approx. 30 per cent of the best earning one (which is not necessarily the winner). Apparently teams that finish outside the top ten constructors (officially there are 12 entries for teams of which one will be filled from 2016 on and the other remains empty) are excluded from these revenues and new entries only become eligible after three competition years.

In summary, the smaller teams in F1 receive a considerably lower share of collectivelyearned media revenues than it is common in other professional sports. Consequently, the allocation of media revenues may be viewed to conserve the competitive advantage of the incumbents and anticompetitively disadvantage smaller outfits and new competitors.

\section{A Rule-Making Cartel?}

The second element of the complaints relates to the way that sporting and technical rules as well as changes of these rules are agreed upon in F1. It refers to the so-called Strategy Group

\footnotetext{
${ }^{3}$ See http://www.autosport.com/news/report.php/id/118955 (2015-10-05).
} 
(SG). According to reports, the SG consists of three groups with equal votes ${ }^{4}$ : the six 'top' teams of F1 - defined as 5 permanent members (Ferrari, Mercedes, Red Bull Racing, McLaren, and Williams), irrespective of recent performance, and the best-of-the-rest team the CRH (represented by Bernie Ecclestone) and the FIA. Next to demonstrating regulatory influence of the $\mathrm{CRH}$, it implies that some competitors in $\mathrm{F} 1$ have an influence on rule changes, while others have not - not exactly representing a level-playing field, in particular in a highly technical sport where technical regulations massively influence the relative competitiveness of the teams.

\section{Violation of Competition Laws?}

The described situation in F1 may be described as a collusive equilibrium where the 100year-monopoly $\mathrm{CRH}$ and the five 'heritage' teams form a (perhaps informal) cartel to mutually protect their rents and prevent competition by the 'non-heritage' teams or newcomers from challenging these rents. The combination of the two aspects - media revenues and rule-making influence - allows them to preserve a financial advantage and a regulatory advantage over their competitors, which represents considerable barriers to compete in a highly technical sport as F1. The defense of the CRH's representative, Bernie Ecclestone, that all the teams signed their individual contract with the $\mathrm{CRH}$ voluntarily ${ }^{5}$, does not convince because the market power of the monopoly-CRH means that the teams basically had to accept the CRH's offer or go out of business.

However, for a cartel between the heritage teams and the CRH to exist, it also requires the $\mathrm{CRH}$ to benefit from the cartel. This may not be so clear at first sight because a more attractive F1 (better competitive balance, more healthy and sustainable competition) should

\footnotetext{
${ }^{4}$ See http://www.forbes.com/sites/csylt/2014/11/26/european-commission-investigating-f1-anticompetition-allegations/ (2014-12-23).

${ }^{5}$ See http://www.autosport.com/news/report.php/id/121081 (2015-10-05).
} 
be good for the $\mathrm{CRH}$ as well. However, looking at the ratio of media revenues and total payments to the teams may shed a light on this. While, for instance, in the Premier League almost 100 per cent of the revenues are allocated to the teams, in F1 the ratio is about 60 per cent. Thus, F1's CRH benefits from having a sufficient number of teams staying away from a collective action to increase this ratio - and, in theory, the heritage payments may exactly have this effect.

This further indicates that the core antitrust problem in F1 is the incontestable 100-year monopoly for the CRH, ironically induced by the 2001 settlement with the European Commission. This monopoly privilege hands the CRH considerable market power that the CRH can easily abuse by keeping a higher share of the revenues and enforcing discriminatory conditions for the different participating teams - but also by excessive pricing of circuit owners, for instance. The latter are required to pay immense and ever-increasing fees to get a slot on F1's limited race calendar, which may be viewed as reaping monopoly rents from auctioning an artificially limited good. Moreover, it is often taxpayer money that subsidizes these fees.

\section{Conclusion}

In summary, a fresh look into the (anti-) competitive structures of F1 appears to be beneficial and necessary. While designed with the best intentions in mind, the real development has exhibited major flaws in the 2001 settlement that has basically shifted the market power away from the FIA and towards the $\mathrm{CRH}$ - but extended rather than limited the abuse potential. While these concerns would warrant - and deserve! - a thorough competition analysis before any anticompetitive conduct or arrangement can be concluded, it does become clear that the 100-year de facto monopoly on exploiting the commercial rights of F1 does not exactly look like a competitive situation. This is even more so, since competitive 
pressure from rival series does not exist (and, from a sporting point of view may actually not be desirable) and competitive pressure from other sports may be rather imperfect. The complaints by Sauber and Force India may be a welcomed opportunity for the European Commission to correct some major flaws of the 2001 settlement. Both in regard to media revenue distribution and rule-making influences, an erosion of the artificial market power of the $\mathrm{CRH}$ - the 100-year-monopoly privilege for a non-market (bargain) price - is overdue. 


\section{Further Reading}

Budzinski, Oliver (2012), The Institutional Framework for Doing Sports Business: Principles of EU Competition Policy in Sports Markets, in: International Journal of Sport Management and Marketing, Vol. 11 (1-2), 2012, pp. 44-72.

Budzinski, Oliver (2014), Competition in Motor Racing: A New Formula One Antitrust Case?, in: Wirtschaftliche Freiheit: Das ordnungspolitische Journal (http://wirtschaftlichefreiheit.de/wordpress/?p=15961) on 24th of December 2014.

Budzinski, Oliver \& Szymanski, Stefan (2015), Are Restrictions of Competition by Sports Associations Horizontal or Vertical in Nature?, in: Journal of Competition Law \& Economics, Vol. 11 (2), 2015, pp. 409-429.

European Commission (2001), Commission Closes Its Investigation into Formula One and Other Four-wheel Motor Sports, IP/01/1523, Brussels.

Müller, Anika \& Budzinski, Oliver (2014), The Economics of Motorsport Centers, in: O. Budzinski / A. Feddersen (Eds.), Contemporary Research in Sports Economics: Proceedings of the $5^{\text {th }}$ ESEA Conference, Frankfurt a.M.: Lang 2014, pp. 293-314. 